\title{
COMPOSITION OF GROUNDMASS MINERALS FROM PETROGRAPHICALLY DISTINCT TYPES OF KIMBERLITES.
}

\section{V.P. Komilova.}

Institute of Geological Sciences. Lenin avenue, 39. Yakutsk, 677982, USSR.

There are several classifications of kimberlite rocks based on their quantitative- - mineralogical composition wherein kimberlite rocks are grouped in terms of the quantity of olivine, phlogopite. Carbonate (Mitchel1.1970) or diopside. phlogopite. monticellite and other minerals (Scinner, Clement,1979). Studies of kimberlites have shown that the rocks that differ in structural-textural characteristics and hence petrogenesis can have a similar mineralogical composition. We believe that massive. microporphyritic kimberlite rocks, which fill dykes and stocks. are related to intrusive facies of kimberlite magmatism, whereas brecciated, medium- and macroporphyritic kimberlites, which fill veins and pipes, are related to subexplosive facies (Kovalsky. 1963; Kovalsky et al..1969; Kornilova et al..1983). Study of groundmass and phenocryst minerals from compositionally similar kimberlite rocks of different facies has revealed certain differences in the compositions of minerals depending on the facies.

Groundmass monticellite and diopside from monticellite- and diopside-bearing intrusive kimberlites, respectively, are richer in $\mathrm{Fe}$ compared to those from similar varieties of kimberlite breccias. Besides kimberlite diopside is characterized by higher $\mathrm{TiO}_{2}$ and $\mathrm{Al}_{2} \mathrm{O}_{3}$ compared to almost pure diopside of the groundmass of kimberlite breccias. Phenocryst olivines. and especially their margins, from monticellite- and diopside-bearing 
kimberlites are on the average richer in $F_{\theta}$ in comparison with olivines from kimberlite breccias.

Mineralogically similar kimberlites of different facies have groundmass ore minerals of similar compositions. However, mineralogically different kimberlites exhibit, irrespective of their facies, substantial differences in titanium, chromium, iron and particularly aluminium contents. Aluminium content of spinel in non-micaceous kimberlites is higher than that of micaceous kimberlites.

Moreover, some intrusive kimberlites are similar in mineralogical composition to alnoite-series rocks associated with alkalic-ultrabasic massifs. Study of the rock-forming minerals of alnoitic rocks from the Tomtor and Chadobetz fields has revealed insignificant differences from intrusive kimberlites.

Our studies show that with mineralogical classification kimberlites which belong to different petrogenetic types and have different quantities of indicator minerals and diamonds fall in one group. No diamonds have so far been found in intrusive kimber 1 ites 